European Corn Borer Conference: On September 7 th and 8th a party of fortythree officials, county agents and farmers from the state of Ohio visited the European Corn Borer Laboratory at Port Stanley, Ont. They arrived at Port Stanley from Cleveland on the afternoon of the seventh, coming across Lake Erie on the Ohio Fish and Game Commission's boat.

The morning of the eighth was spent in visiting the laboratory and then a trip was made in motor trucks to some of the more heavily infested fields. Stops were also made at the Dominion Government experimental control plots and at different fields where corn had been planted in accordance with suggestions made by the officers of the Entomological Branch. It was readily seen that late planted corn suffered less injury from the European corn borer as compared with that planted earlier in the season.

The object of the trip, which was organized by the Ohio Department of Agriculture, was to bring to the attention of the farmers and county agents of that state the necessity of cooperative action in sections where the European corn borer is present and doing extensive damage. The visitors returned to Cleveland by boat on the afternoon of the eighth.

The party was in charge of Mr. L. J. Taber, Director of Agriculture for Ohio, and included E. C. Cotton, Director of Plant Industry. Columbus; Prof. Raymond C. Osburn, Ohio University; Prof. Herbert Osburn, Ohio University; H. A. Gossard, State Entomologist; J. S. Houser, Assistant State Entomologist; T. H. Parks, Extension Entomologist, and N. E. Shaw, Columbus. Mr. W. A. Walton, Chief of the IDivision of Forage Insects, and Mr. L. H. Worthley, in charge of Corn Borer Control, of the United States Department of Agriculture accompanied the visitors.

Mr. I. S. McLaine, Chief of the Division of Foreign Pests Suppression and Messrs. Crawford and Kcenan of the Entomological Branch and Capt. G. J. Spencer of the Ontario Department of Agriculture, conducted the party through the infested area.

\title{
THIRTY-FIFTH ANNUAL MEETING OF THE AMERICAN ASSOCIATION OF ECONOMIC ENTOMOLOGISTS
}

The 35th annual meeting of the American Association of Economic Entomologists will be held at Boston, Mass., December 28 to $30,1922$.

The day sessions will be held at the Massachusetts Institute of Technology, Cambridge, and at least one evening session will be held in the Auditorium of the Boston Society of Natural History.

Hotel headquarters will be at the Brunswick, Boylston Street, near Copley Square. As hotels are likely to be crowded during the Christmas holidays, members are urged to secure reservations by corresponding direct with the hotel at once.

During convocation week, it is planned to hold a joint meeting with the American Phytopathological Society. Members interested in medical entomology will hold a joint session with Section $N$, and the entomologists especially interested in extension work and in the Insect Pest Survey plan will hold special group meetings.

Applications for membership should be filed with the Secretary as early as possible, and should be accompanied with the fee of $\$ 3.50$. Application blanks can be secured from the Secretary or the chairman of the membership committee.

A. F. Burgess, Secretary

Melrose Highlands, Mass. 